УДК 821.161.2-343.091

Полтава+Симоненко

Варданян М. В., кандидат філологічних наук Криворізький державний педагогічний університет

\title{
«УКРАЇНА-СВОЯ-ЧУЖА»: ІДЕНТИФІКАЦІЙНИЙ ПРОСТІР КАЗОК ЛЕОНІДА ПОЛТАВИ ТА ВАСИЛЯ СИМОНЕНКА
}

У статті розглядаються жанрові особливості казок Василя Симоненка «Цар Плаксій і Лоскотон», «Подорож у країну Навпаки» та Леоніда Полтави «Казка про Чародія-лиходія, Івасика-козачка і Чорне море». Алегоричні казки аналізуються крізь призму концепту Україна-своя-чужа. Проблема ідентичності висвітлюється на кількох рівнях екзистенційному, аксіологічному та поетикальному. На екзистенціальному рівні означено проблему чужості в життєтворчості митиів - дисидента та експатріанта. На аксіологічному рівні визначено систему иінностей у поетичному світі обох письменників з ї концептами - Украӥна, рідна земля, рідний народ, мова. інший.

Ключові слова: казка, діаспорна література для дітей та юначтва, свій-чужий-

В статье рассматриваются жанровые особенности сказок Василия Симоненко «Царь Плакса и Лоскотон», «Путешествие в страну Наоборот» и Леонида Полтавы «Сказка о Чародее-злодее, Ивасика-казачка и Черное море». Аллегорические сказки анализируются через призму кониепта Украина-своя-чужая. Проблема идентичности освещается на нескольких уровнях - экзистенциальном, аксиологическом и поетикальном. На экзистенциальном уровне обозначено проблему чуждости в жизнетворчестве художников - диссидента и экспатрианта. На аксиологическом уровне определена система ценностей в поэтическом мире обоих писателей с ее концептами - Украина, родная земля, родной народ, язык. другой.

Ключевые слова: сказка, диаспоры литература для детей и юношества, свой-чужой-

This article analyzes genre features of fairy tales by Vasyl Symonenko "King Plaksiy and Loskoton», "Journey to Vice Versa country» and Leonid Poltava "The tale of the Villain Sorcerer, Ivasyk Cossack and the Black Sea». Allegorical tales are investigated through the prism of the «native and alien Ukraine» concept. Identity problem is covered on the following levels, such as existential, axiological and poetic one. The existential level defines the problem of alienation in the life writing of above mentioned writers (dissident and expatriate). The axiological level sets the value system in the poetic world of both writers including the concepts of Ukraine, native land, native people, language.

Keywords: fairy tale, diaspora literature for children and youth, native-allien-another.

Літератури світу: поетика, ментальність і духовність. - 2017. - Вип. 8. 
У сучасній науці, зокрема і літературознавчій, все гостріше постає питання національної ідентичності й глобалізації, що висвітлюються крізь призму опозиції свій / чужий, свій - чужий - інший. Почасти вчені, які опинилися за межею свого, артикулюють ідентифікаційний дискурс. Марія Ревакович («Гендер, географія, мова: у пошуках ідентичності в сучасній українській літературі»), Кшиштоф Чижевський («Чужий - Інша - Свої: розмова над берегом ріки»), Юлія Кристева («Самі собі чужі») - це лише одиничний перелік тих, доля яких провадила лінією еміграції, а їхні праці охоплюють різні аспекти проблеми чужості та ідентичності. Ці питання дотичні до української літератури XX ст., зокрема як творів письменників-емігрантів, так материкової України. Спробуємо розглянути у цій статті ідентифікаційний простір казок двох постатей Леоніда Полтави та Василя Симоненка крізь призму концепту Україна-своя-чужа. Ця проблема представлена в аналізованих творах на екзистенційному й аксіологічному та поетикальному рівнях. У такому аспекті Л. Горболіс у своїй монографії «Чужина: коди інтерпретації» дослідила спадщину українців різних періодів, у житті і творчості яких еміграція ставала реалією.

Попри те, що В. Симоненко та Л. Полтава належать до різних світів українського культуропростору - материковий / діаспорний, їх єднає проблема чужості. «Хто такий чужинец̧ь? - запитувала у свої праці Ю. Кристева та відповідала: - Той, хто не входить до складу групи, той, хто нею не $\epsilon$, інакший» [Кристева 2004:123]. На психологічному рівні ця чужість виявляється у складності «жити як інший $i$ з іншими» [Кристева 2004:134]. I таким $\epsilon$ екзистенційний модус життєтворчості В. Симоненка як діяча українського руху опору радянському режиму 1960-70-х рр. Л. Полтава - експатріант, який, за образним виразом Ю. Кристевої, «втратив матір». Вивезений за часів Другої світової війни на примусові роботи до Німеччини, Л. Полтава мав лишитися блукати чужиною - Францією, Іспанією, США, але завжди жив на «лінії повернення» (К. Чижевський) до незалежної України, звільненої від «совєтської окупації». 
Такий екзистенційний простір Л. Полтави та В. Симоненка означує обох митців як вигнанців у своїй-чужій-Україні, що проектується на їхні художні твори, як своєрідні ключі, в яких проблема формування моделі національної ідентичності набуває особливого значення. Обидва письменники прагнули одного - за допомогою художнього слова протистояти тогочасній тоталітарній машині та піднести українську націю. Це стало своєрідними маркерами ідентифікаційного простору символічних, алегоричних казок Л. Полтави та В. Симоненка. Україна-своя - концепт національної ідентичності, до пріоритетів якої відкриті як автори творів, так і їхні герої. Натомість Украӥначужа охоплює закритий, ворожий, руйнівний простір, породжений тоталітарним режимом. Обрати шлях самоідентифікації зі своєю, не чужою Україною - є лейтмотивом казок обох митців.

Критичне ставлення до радянської дійсності прочитується у всіх трьох віршованих казках В. Симоненка. За слушним спостереженням В. Марка, «до символізації образної системи, щчо була запереченням поетики сочреалізму, В. Симоненко йшов через алегоричні образи байок, казок і легенд філософського змісту, де образи тяжіють до символів за законами жанру» [Марко 2013:120]. Приміром, «Казка про Дурила» вважається «лебединою піснею» письменника, але вийшла вона друком лише 1987 року. Унеможливлювало публікацію розкрита в алегоричній формі тема трагічної долі українського народу. У творі викривалася сталінська диктатура, антиутопічне тоталітарне правління 3 його ідеєю про світле сонцесяйне майбутне.

Адаптованою для дитячого сприйняття і варіацією тієї ж теми є казки «Цар Плаксій і Лоскотон» (1963) і «Подорож у країну Навпаки» (1964), які майже одразу ж надрукувалися та виходили кількома виданнями. За канонами жанру фантастичної казки у «Подорожі у країну Навпаки» $\epsilon$ чарівник-дідусь та загадкова країна Навпаки («С чудна одна земля - / Там ні дня нема, ні ночі, / Кожен робить там, що схоче...» [УЛД 2011:516]), куди переносяться хлопчаки Лесик, Толя й два Володі, незадоволені своїм життям. Подорож дітей втілена у 
динамічному, пригодницькому сюжеті з розвагами і розбишацтвом, втечами i переслідуваннями у країні Навпаки, що певним чином нагадує країну Розваг Карла Коллоді 3 «ригод Піноккіо».

Водночас за гумором і розважальністю приховується сатиричний зміст на тогочасну авторові дійсність і тоталітарну державу з іï анархічним устроєм. Як слушно зауважувала Л. Горболіс, «Радянська система загрожувала нациіональній ідентичності украӥнциів, породжувала в громадянина невпевненість $і$ страх, деструктурувала його духовні начала, морально-етичні принщиии» [Горболіс 2016:45-46]. Такі ознаки у казці В. Симоненка містить алегорична країна Навпаки. Нею править вождь 3 охоронцями того ладу, що втілюють гротескні образи Царя Великого Невмиваки і його свити вояків на свинях. Через діалог Царя з підданими письменник викриває репресії влади до людей, несхожих на інших, та ув'язненнями тих, які не вписуються у жорсткі канони: «Що цуе в біса за прояви? / В них праворуч руки праві?! / Чом вони очима бачать? / Що цее, слуги мої, значить? / Треба їх обмить чорнилом, / Бо від них одгонить милом. / Потім всім їм для науки / Треба викрутити руки, / Ще й відтяти треба вуха / Та навчить очима слухать. / Лиш тоді изі диваки / Зможуть жити в Навпаки. / A тепер и̧их недотеп / Замуруйте в темний склеn!» [УЛД 2011:518]. У такий спосіб В. Симоненко викриває радянське суспільство з претензією на космополітизм, який, за виразом Ю. Кристевої, «похитнув ідентичність того, хто у спільноті свойх себе вже не пізнає» [Кристева 2004:189]. Проте в ідентифікаційному просторі казки діти не скоряються грізному Цареві і тікають з підземелля, що є своєрідним закликом В. Симоненка протистояти беззаконню і бути сильним духом. Тому казка має оптимістичну кінцівку: морально перероджені хлопчаки знову вдома, що втілює ідею автора про повернення до рідних коренів, відродження національної свідомості кожного українця.

Тема нескореності злу та обстоювання ідеї майбутнього української нації об’єднує патріотичні казки В. Симоненка «Цар Плаксій та Лоскотон» та Л. Полтави «Казка про Чародія-лиходія, Івасика-козачка і Чорне море». За 
жанровими особливостями казки, обидва твори мають традиційний початок («Там, де гори $і$ долини <..> Був на троні изар Плаксій» та «Жив на світі Чародій...») і кінцівку («Схочеш сам піти в цеей край, / То мармрут запам'ятай...» та «Це давно було, минулось...»). Україна-своя-чужа означена у творах географічними топосами: у казці В. Симоненка алегорією України виступає країна Сльозолий, натомість у Л. Полтави - містами Київ і Львів, Карпатські й Кримські гори, Дніпро, Чорне море. Все це спрямовано на відкриття України в усій різноманітності та величі, з їі легендами та звичаями, серед яких і походження назви Чорного моря, що прибрало такого кольору по смерті Чарівника: «Бо ж загинув Чародій, України Лиходій, / Хоч його пекельний гнів / Синє море й почорнив! < ..> Це давно було, минулось, / Тільки назва не забулась - / Чорне море, - $з$ тих часів / Дожило до наших днів» [Полтава]. Відтак в ідентифікаційному просторі казок увиразнюються образи народних героїв, наратив рідного краю, історичної пам'яті, що виступають ознаками національної ідентичності.

Будуючи художній світ творів на антитезі, письменники групують персонажів на добротворців (Івасик-козачок у Л. Полтави, Лоскотон у В. Симоненка) та злотворців (відповідно - змій Чародій та цар Плаксій). Уособленням зла у казці Л. Полтави $є$ багатоликий $\mathrm{i}$ нездоланний Чародій-Лиходій, який зображений наступним чином: «Важко ворога здолати, / Як несила упізнати: / Мав він тридиять три лицяя / I міняв їх без кіния!» [Полтава]. Певно, така характеристика алегоричного образу символізує багатьох недоброзичливців України та ऑiі народу, що формують простір України-чужої. Підсилюється розкриття цього уособлення і через перетворення Чародія: спочатку на потворного змія-велета, який прагне зруйнувати духовний центр України - Київ; згодом на невидимий дим у Львові - як кодування невідомих, прихованих ворогів української нації; далі у «чорну хату - чорне лихо», куди «тисячі входять, але звідти не виходять» - символізує репресійну тоталітарну машину; потім у дорогу - як заклик не збитися на невірний шлях, аби не згубити себе, свою націю і Батьківщину («Хто дорозі тій повірить, / 
Піде нею, а тоді / Потрапляв він у вири / I зникає у воді! Не один отак загинув, / Може б всенька Украӥна / Вже загинула б отак!» [Полтава] - все це своєрідні життєві долі українського народу в просторі України-чужої. Зливається Чародій із Дніпром, руйнуючи села, також впадає у море, де знаходить свою загибель від Івасика та його армії як уособлення національних героїв українців.

Головний персонаж казки Івасик розкривається як відважний, розумний, національно свідомий, патріот свого народу і краю («Все зроблю для Украӥни, / Найріднішої землі!» [Полтава]), близький із природою (йому допомагають звірі, птахи, риби), може згуртувати і повести за собою на боротьбу проти зла («Воювати проти горя / Треба навіть на дні моря!»[Полтава]). Зображуючи образ головного героя, автор вдається до народної символіки та образності блакитний жупан, щабелька, називає його козаком. Як справжній ватажок, він уміє об’єднати народ, повести за собою задля великої ідеї української державності. Тому-то рефреном проходять рядки у казці: «Тільки ті, щзо всі встають, / Перемоги зазнають!» [Полтава]. У такий спосіб возвеличується сила народу, його здатність повстати проти всезагального лиха задля Українисвоєї. Такі конотації означуються маркерами історичної пам'яті, що формують модель національної ідентичності для молодого покоління.

Якщо у Л. Полтави протистоїть лихому багатоликому Чародію хлопчина, то головний герой казки В. Симоненка вже дорослий веселун, добрий, лагідний, сміливий Лоскотон, який приносив сміх у кожну хату країни Сльозолий. Прототипом головного героя Лоскотона став сам письменник. В. Симоненко 3 любов’ю ставиться до своєї країни, за долю якої вболіває. Тому називає ї̈ красою-країною, диво-царством, яка водночас страждає, сповнена горя і сліз. Тому-то автор вибудовує образ нескореного героя, який обрав нелегкий шлях заради служіння народові і Батьківщини - мандри, митарство, переслідування, що визначали життєвий модус самого В. Симоненка. Як і його герой, він має теплу i щиру вдачу. Портретна характеристика Лоскотона вимальовується із симпатією: очі з лукавинкою, лоскотливі вуса, м’яке волосся. Герой не боїться 
перешкод, зневажає беззаконня грізного Плаксія та покликаний нести щастя, сміх і злагоду - у цих інтенціях відчутний голос автора.

Головному образу-ідеї Лоскотону протиставлений Плаксій. Контрастність цих персонажів підкреслена і в назві твору через концепти плач / сміх. Адже вибір імен також символічний: перший - то носій ідеї горя, лиха, другий щастя, радості. Образ самого Царя країни Сльозолий зображений гротескно: має голову, мов бочку, а очі - ніби кавуни [УЛД 2011:424]. Він жорстокий i лихий, бо любить пити сльози, забороняє радіти і сміятися. Такою ж іронічною є характеристика його дочок Нудоти, Вай-Вай, Плакоти, синів Плаксунів, які цілий день сиділи, голосили, сопіли, стогнали та ревли. Мав він грізну гвардію забіяк-сльозівців, які шмагали нагайками тих, хто сміється, та п’яницьвартових. Їх очолює бридкий, лютий посіпака, віроломний як змія, підлабузник капітан Макака. Співають солодких пісень Цареві гладкі поети-віршомази. Письменник саркастично викриває правління грізного диктатора, що уособлює тоталітарну систему в чужій-Україні, зокрема цензурні заборони, поліцейське свавілля, арешти, репресії, авторитарність влади, ув’язнення інакодумців, голод i бідність. Підсумок автора невтішний: «Так щуо в цүарстві тому скрізь / Вистачало плачу ц̌ сліз» [УЛД 2011:424]. За автором, такий устрій алегоричного Плаксія не має майбутнього, а народ підтримає нескорених борців в особі Лоскотона проти режиму: «...рознесли всі перепони, гнули грати, мов прути...» [УЛД 2011:426]. Ця далекоглядність поета втілена у фіналі казки: «Так веселий Лоскотон / Розвалив поганський трон» [УЛД 2011:427], що закодовують мрію В. Симоненка про самостійну українську державність.

На відміну від казки В. Симоненка ідея твору Л. Полтави виражена емпліцитно: «Проти всіх $і$ ти не вдієм, / Нас - мільйони бойові! Ти загинеш. Лиходію, / Ми ж залишимось живі / У діброві, у дружбі й мирі - / Люди, риби, птахи, звірі! <..> Щоб загинув Чародій, / Украӥни Лиходій!» [Полтава], що постають своєрідним закликом до боротьби і вірою у перемогу. Як письменникнаціоналіст Л. Полтава сповідує ідея української державності, звільнення від чужинського панування, утвердження єдності нації. I як активний громадський, 
культурний діяч діаспори, він навіть у казці для дітей не зраджує своїм прагненням аби про Україну знав увесь світ, про що можуть свідчити такі рядки: «Про події в Україні / Слух пішов у всі країни; / Всі раділи на землі, / I дорослі, і малі: / Люди, звірі, черепахи, / Риби, птахи і комахи, / Бо ж загинув Чародій, / України Лиходій...» [Полтава]. У цих міркування розкривається глибоко патріотична душа письменника, який носив Україну в серці, відкриваючи іiі світові.

На останок додамо, що обидва письменники виявили себе як справжні гуманісти, націоналісти, для яких доля i майбутнє Батьківщини стоять на першому місці. В ідентифікаційному просторі їхніх казок перевага надається Україні-своїй, що створює своєрідну модель формування національної ідентичності молодого покоління. У такий спосіб за допомогою фантазії і вигадки у казках для дітей та юнацтва митці розбудовують систему цінностей 3 iii концептами - Україна, рідна земля, вірний син-ватажок, рідний народ.

У виборі асимілюватися з чужим чи залишитися за межею іншого, письменники - Леонід Полтава та Василь Симоненко - обирають статус «людей пограниччя», що шукали порятунку в писанні та не втрачали віри на повернення України-своєї - географічної, історичної, духовної, ментальної та політичної. Такі рецепції літератури для дітей та юнацтва з позиції свій-чужийіниий вважаємо за перспективний напрямок дослідження 3 огляду на становлення України як політичної нації та утвердження національної ідентичності українців. Осмисленню цієї проблеми завдячуємо Канадському інституту українських студій Альбертського університету, 3 Вічного фонду імені родини Ремезів якого здійснюється фінансова підтримка проекту 3 дослідження української діаспорної літератури для дітей та юнацтва.

\section{БІБЛІОГРАФІЯ}

Горболіс 2016 - Горболіс Л. Чужина: коди інтерпретації : монографія / Л. М. Горболіс. - Суми : ВВП «Мрія», 2016. - 176 с. 
Кристева 2004 - Кристева Ю. Самі собі чужі / Юлія Кристева ; перек. 3 фр. 3. Борисюк. - Київ : Видавництво Соломії Павличко «Основи», 2004. $263 \mathrm{c}$.

Марко 2013 - Марко В. Дороги Василя Симоненка // Марко В. П. Аналіз художнього твору : навч. посіб. - К. : Академвидав, 2013. - С. 118-127.

Полтава - Полтава Л. Казка про Чародія-лиходія, Івасика і Чорне море [Електронний ресурс] / Леонід Полтава // Весела абетка. - Режим доступу до тексту: http://abetka.ukrlife.org/charod.html.

Ревакович 2012 - Ревакович М. Гендер, географія, мова: у пошуках ідентичності в сучасній українській літературі / Марія Ревакович. - Львів : Центр гуманітарних досліджень ; Київ : Смолоскип, 2012. - 72 с.

УЛД 2011 - Українська література для дітей: хрестоматія: навчальний посібник для студентів вищих навчальних закладів / Упоряд. А. I. Мовчун, 3. Д. Варавкіна. - К. : Арій, 2011. - 680 с.

Чижевський 2011 - Чижевський К. Чужий - Інша - Свої: розмова над берегом ріки / Кшиштоф Чижевський. - Львів : Центр гуманітарних досліджень ; Київ : Смолоскип, 2011. - 96 с. 